LETTER TO THE EDITOR

\title{
Reply to Sykes and Cozzi: 'Xenotransplantation of porcine neonatal islets of Langerhans and Sertolli cells'
}

\author{
Rafael Valdés-González \\ Laboratorio de Xenotrasplantes, Hospital Infantil de México 'Federico Gómez', 4 piso Edificio Mundet, Calle Dr. Márquez 162, Col. Doctores, \\ C.P. 06720 México, D.F. México
}

(Correspondence should be addressed to R Valdés-González; Email: rvaldes@xenomexico.org)

The concerns expressed by Drs Sykes and Cozzi have already been raised in other publications and we have responded to them $(1,2)$. In particular, we would like to point out that this trial started in 2000 , and therefore we are surprised that the authors would be concerned that at that time we did not follow their own position papers published in 2003 and 2004 . As pointed out in our paper (3), the project was locally approved by two institutional review boards, in addition to federal-level agencies such as the National Transplant Center and the National Bioethics Committee. It was also carried out according to article 32 of the Helsinki Declaration. All animals used were specific pathogen-free, and the protocol and the informed consent letters stressed the need for long-term follow-up, with both patients and their families being monitored regularly for any complication or infection. We intend to continue this monitoring indefinitely. It is noteworthy that there have not been any complications in the 5 years since the trial started. Together with this trial, there is a growing body of evidence that has lowered the expected risk of complications that could be a public health concern $(4,5)$. As we expressed in the paper, intensive insulin therapy only delays the onset of complications, but it does not avoid them (6), whereas islet allotransplantation still carries the risk of infection, and also requires lifetime immunosuppression, together with the risk of secondary complications that range from hemorrhage and mouth ulcers, to hepatic steatosis (7). We regret that the International Xenotransplantation Association (IXA) has decided that its guidelines be applied retroactively, which would censor work in progress that was started years before it published its position. We believe that the free exchange of ideas and results such as those published in the European Journal of Endocrinology (3) can only be of benefit to diabetic patients worldwide. The World Health Assembly resolution cited by the authors calls for 'national regulatory control' but does not require a specific agency devoted to xenotransplantation, as the IXA suggests. Mexican Health Law has a Transplantation Regulation that specifically encompasses xenotransplantation, and the highest health authorities in Mexico are supervising this work. It is noteworthy that the same resolution also calls for 'harmonizing world practices' in xenotransplantation, and asks the Director General to 'obtain worldwide data to evaluate practices of xenogeneic transplants'. The request for censoring data that do not comply with IXA standards would seem to be contrary to the spirit of this resolution.

\section{References}

1 Valdés R. Xenotransplantation trials. Lancet 20023592281.

2 Valdés-González R. Xenotransplantation's benefits outweigh risks. Nature 2002419268.

3 Valdés-González RA, Dorantes LM, Garibay GN, Bracho-Blanchet E, Mendez AJ, Dávila-Pérez R, Robert B, Elliott RB, Terán L \& White DJG. Xenotransplantation of porcine neonatal islets of Langerhans and Sertoli cells: a 4-year study. European Journal of Endocrinology 2005 $153419-427$.

4 Fishman JA \& Patience C. Xenotransplantation: infectious risk revisited. American Journal of Transplantation 20044 1383-1390.

5 Di Nicuolo G, van de Kerkhove MP, Hoekstra R, Beld MG, Amoroso P, Battisti S, Starace M, di Florio E, Scuderi V, Scala S, Bracco A, Mancini A, Chamuleau RA \& Calise F. No evidence of in vitro and in vivo porcine endogenous retrovirus infection after plasmapheresis through the AMC-bioartificial liver. Xenotransplantation 200512 286-292.

6 The Diabetes Control and Complications Trial Research Group. The effect of intensive treatment of diabetes on the development and progression of long-term complications in insulin-dependent diabetes mellitus. New England Journal of Medicine 1993329 977-986.

7 Bhargava R, Senior PA, Ackerman TE, Ryan EA, Paty BW, Lakey JR \& Shapiro AM. Prevalence of hepatic steatosis after islet transplantation and its relation to graft function. Diabetes 2004 53 1311-1317.

Received 10 February 2006

Accepted 3 March 2006 